\title{
Rapid Eye Movement Sleep Is Reduced in Prolactin-Deficient Mice
}

\author{
Ferenc Obál Jr, ${ }^{1,2 \dagger}$ Fabio Garcia-Garcia, ${ }^{1}$ Balint Kacsóh,${ }^{3}$ Ping Taishi, ${ }^{1}$ Stewart Bohnet, ${ }^{1}$ Nelson D. Horseman, ${ }^{4}$ and \\ James M. Krueger ${ }^{1}$ \\ ${ }^{1}$ Department of Veterinary and Comparative Anatomy, Pharmacology, and Physiology, College of Veterinary Medicine, Washington State University, \\ Pullman, Washington 99164-6520, ${ }^{2}$ Department of Physiology, University of Szeged, A. Szent-Gyorgyi Medical Center, 6720 Szeged, Hungary, ${ }^{3}$ Division of \\ Basic Medical Sciences and Department of Pediatrics, Mercer University School of Medicine, Macon, Georgia 31207, and ${ }^{4}$ Department of Molecular and \\ Cellular Physiology, University of Cincinnati, Cincinnati, Ohio 45267-0576
}

Prolactin (PRL) is implicated in the modulation of spontaneous rapid eye movement sleep (REMS). Previous models of hypoprolactinemic animals were characterized by changes in REMS, although associated deficits made it difficult to ascribe changes in REMS to reduced PRL. In the current studies, male PRL knock-out (KO) mice were used; these mice lack functional PRL but have no known additional deficits. Spontaneous REMS was reduced in the PRL KO mice compared with wild-type or heterozygous littermates. Infusion of PRL for 11-12 d into PRL KO mice restored their REMS to that occurring in wild-type or heterozygous controls. Six hours of sleep deprivation induced a non-REMS and a REMS rebound in both PRL KO mice and heterozygous littermates, although the REMS rebound in the KOs was substantially less. Vasoactive intestinal peptide (VIP) induced REMS responses in heterozygous mice but not in KO mice. Similarly, an ether stressor failed to enhance REMS in the PRL KOs but did in heterozygous littermates. Finally, hypothalamic mRNA levels for PRL, VIP, neural nitric oxide synthase (NOS), inducible NOS, and the interferon type I receptor were similar in KO and heterozygous mice. In contrast, tyrosine hydroxylase mRNA was lower in the PRL KO mice than in heterozygous controls and was restored to control values by infusion of PRL, suggesting a functioning short-loop negative feedback regulation in PRL KO mice. Data support the notion that PRL is involved in REMS regulation.

Key words: stress; VIP; sleep deprivation; rapid eye movement; sleep; prolactin

\section{Introduction}

The first anecdotal account implicating prolactin (PRL) in rapid eye movement sleep (REMS) reported that systemic administration of exogenous PRL enhances REMS in hypophysectomized pontine cats (Jouvet et al., 1986). Since then, much evidence suggests that PRL modulates REMS (Roky et al., 1995; Obál and Krueger, 2000). Intracerebral or systemic administration of PRL enhances REMS but not non-REMS (NREMS) in rats, rabbits, and mice (Obál et al., 1989; Roky et al., 1993). Rats rendered chronically hyperprolactinemic, by means of grafting pituitaries under the kidney capsule, exhibit increases in REMS during daylight hours (Obál et al., 1997). Both REMS and NREMS are en-

\footnotetext{
Received June 22, 2005; revised Sept. 28, 2005; accepted Sept. 28, 2005.

This work was supported by grants from the National Institutes of Health (NS31453 and NS27250 to J.M.K., DK52134 to N.D.H.), the Hungarian National Foundation (OTKA-T-043156 to F.O.), and the Ministry of Health (ETT103 04/2003 to F.0.). Dr. Ferenc Obál Jr. died during the course of this work. He gave us the inspiration and leadership for this work as well as performed many of the primary experiments reported herein. We thank Dr. Bryan Slinker for his help with the statistical analyses. We also thank Richard Brown for breeding the mice.

${ }^{\dagger}$ Deceased, June 29, 2004

Correspondence should be addressed to Dr. James M. Krueger, Department of Veterinary and Comparative Anatomy, Pharmacology, and Physiology, Washington State University, P.0. Box 646520, Pullman, WA 99164-6520. E-mail: Krueger@vetmed.wsu.edu.

F. Garcia-Garcia's present address: Universidad Veracruzana, Instituto de Ciencias de la Salud, Col. Industrial Animas, C.P. 91190, Xalapa, Veracruz, Mexico.

DOI:10.1523/JNEUROSCI.2572-05.2005

Copyright $\odot 2005$ Society for Neuroscience $\quad$ 0270-6474/05/2510282-08\$15.00/0
}

hanced in hyperprolactinemic pseudopregnant rats (Zhang et al., 1995). In humans, plasma levels of PRL are REMS related and highest in the early morning hours (for review, see Roky et al., 1995; Obál and Krueger, 2000). In animal models of stress, either restraint stress or ether vapor exposure stress, elevated plasma PRL levels are associated with increases in REMS (Bodosi et al., 2000; Meerlo et al. 2001). Vasoactive intestinal polypeptide (VIP) releases pituitary PRL and enhances REMS (Obál et al., 1986, 1994). Similarly, other PRL-releasing peptides such as pituitary adenylate cyclase-activating peptide and peptide histidine methionine also promote REMS (Fang et al., 1995) Anti-PRL antibodies block VIP-enhanced REMS (Obál et al., 1994). Anti-PRL antibodies also reduce spontaneous REMS in rats (Obál et al., 1992) and block REMS induced by systemic VIP (Obál et al., 1994). Collectively, such data suggest PRL may modulate REMS.

Animal models with various PRL deficiencies also suggest a REMS modulating action of PRL. Thus, in mutant hypoprolactinemic rats, REMS is suppressed during the light period but enhanced during the dark period (Lobo et al., 1999). In a mutant mouse model, mice lacking an interferon type I receptor have very low levels of hypothalamic PRL mRNA and approximately a $30 \%$ reduction in REMS during both daylight and night hours (Bohnet et al., 2004). However, previously, REMS has not been evaluated in animals lacking PRL. In the current study, we report that REMS is reduced in mice that produce a biologically inactive 
$11 \mathrm{kDa}$ PRL-immunoreactive polypeptide because of a targeted disruption of the PRL gene (Horseman et al., 1997). We also report that REMS is restored in these mice with PRL therapy and that their REMS responses to VIP and ether stress are attenuated.

\section{Materials and Methods}

Homozygous wild-type $(+/+)$, heterozygous $(-/+)$, and homozygous PRL knock-out $(-/-)$ male mice, which had been made congenic on C57BL/6J by eight backcross generations, were used. Mice were developed initially by one of us (N.D.H.) (Horseman et al., 1997) and bred by mating $(-/+)$ females with $(-/-)$ males; heterozygous females lactate, thereby indicating that they have sufficient PRL for that purpose, and it allows them to be used for breeding without having to use surrogate mothers. Mice were genotyped at 3-4 weeks of age from tail-tip samples as described previously (Horseman et al., 1997). At 8-16 weeks of age, mice $(25-30 \mathrm{~g})$ were housed individually in Plexiglas cages placed in environmental chambers on a $12 \mathrm{~h}$ light/dark cycle at $30^{\circ} \mathrm{C}$ ambient temperature. Food and water were available continuously. Breeding and experimental protocols were approved by the Washington State University Animal Care and Use Committee.

\section{Surgery}

The mice were anesthetized using ketamine-xylazine $(87$ and $13 \mathrm{mg} / \mathrm{kg}$, respectively). Stainless steel screw electrodes were placed on the top of the dura mater over the frontal and parietal lobes and the cerebellum. These electrodes were used to record the electroencephalogram (EEG). Two stainless steel wires were implanted into the dorsal neck muscles to record the electromyogram (EMG). The EEG and EMG electrodes were connected to a pedestal $(0.4 \mathrm{~g})$ implanted on the top of the skull. The surgeries were performed $7 \mathrm{~d}$ before recordings began.

\section{Recording of sleep-wake activity}

The mice were connected to lightweight recording cables and habituated to the experimental conditions during recovery (Bohnet et al., 2004). The cables were attached to commutators that were connected to amplifiers. The signals were digitized ( $128 \mathrm{~Hz}$ sampling rate) and collected by a computer and stored on compact discs. Power density spectra $(0.25-15.0$ $\mathrm{Hz}$ in $0.5 \mathrm{~Hz}$ bands) were calculated on-line for consecutive $10 \mathrm{~s}$ EEG epochs and stored with the EEG and EMG signals. For scoring, the EEG and EMG signals and the power density spectra were restored on the computer screen. The states of vigilance were determined for $10 \mathrm{~s}$ epochs (Morrow and Opp, 2005) by the usual criteria as NREMS (highamplitude EEG slow waves and low muscle tone), REMS (highly regular theta EEG activity and loss of muscle tone with occasional twitches), and wakefulness (EEG activities similar to, but often less regular and with lower amplitude than, those in REMS and high EMG activity). The percentage of the time spent in each state of vigilance for $1 \mathrm{~h}$ periods was determined. The power values for the $0.5-4.0 \mathrm{~Hz}(\Delta)$ frequency range were integrated. The mean of these integrated values was calculated for uninterrupted periods of artifact-free NREMS and used as an index of EEG slow-wave activity (SWA) during NREMS to characterize sleep intensity (depth of sleep) in each recording hour (EEG SWA data shown in Fig. 4). The absolute power density values (squared microvolts) were determined for $0.5 \mathrm{~Hz}$ frequency bins from $0-15 \mathrm{~Hz}$ during both NREMS and REMS. These values were then expressed as the percentage of total power $(0-15 \mathrm{~Hz})$ in each 0.5 frequency bin; these values are shown in Figure 2.

\section{Experimental schedule}

Spontaneous sleep. Spontaneous sleep was determined in two separate experiments. First, wild-type mice $[(+/+) ; n=10]$ and heterozygous mice $[(+/-) ; n=12]$ were compared. In a second experiment, another group of $(+/-)$ mice $(n=10)$ was used for comparison with PRL knockout mice $[(-/-) ; n=10]$. Most of the latter two groups were also used for PRL replacement (see below) and sleep deprivation (SD). Mice were recorded from for 2 consecutive days to obtain baseline values of spontaneous sleep-wake activity. On the third experimental day, the $(+/-)$ and $(-/-)$ mice were deprived of sleep. SD started at light onset (time 0 in the figures) and lasted for 6 h. The EEG and EMG were recorded throughout SD, during the remaining $6 \mathrm{~h}$ of the light period, and for $11 \mathrm{~h}$ during the subsequent dark phase (collected data were backed up during the last hour of the dark period, and the records in this hour were discarded). SD was performed by gentle handling while the mice stayed in their home cage; whenever behavioral or EEG signs of sleep were observed, the mice were aroused by knocking on the cage or lightly touching them. It is assumed that stress is not a major factor determining the sleep response to SD, at least when SD is performed by gentle handling (Jouvet, 1994), although sleep loss itself may represent a stressor and may alter hypothalamo-pituitary-adrenal functions (Krueger et al., 1990).

$P R L$ replacement. The mice used in the PRL replacement experiment $[n=6(+/-)$ mice, $n=10(-/-)$ mice $]$ were implanted subcutaneously with osmotic mini-pumps $(0.25 \mu \mathrm{l} / \mathrm{h}$ for $14 \mathrm{~d}$; Alzet 1002; Durect Corporation, Cupertino, CA) in the back (weight after loading, $0.5 \mathrm{~g}$ ) (the same mice were used for spontaneous sleep determination; the ALZET pumps were implanted during a second surgery after spontaneous sleep was determined). The minipumps were filled with mouse PRL in physiological saline delivering $4.6 \mu \mathrm{g}$ of PRL per day in $(-/-)$ mice. For $(+/-)$ mice, saline was infused. Spontaneous sleep-wake activity of the mice implanted with the minipumps was recorded on day 11 and/or 12 of the infusion. The PRL preparation was for in vivo use and was a gift from Dr. A. F. Parlow (The National Hormone and Pituitary Program, National Institute of Diabetes and Digestive and Kidney Diseases, Bethesda, $\mathrm{MD})$. After recordings were obtained, mice were killed and blood samples were taken for determination of PRL levels; only those mice showing circulating PRL were used for sleep and statistical analyses.

VIP treatment. Twelve $(+/-)$ and $12(-/-)$ mice received intraperitoneal injection of physiological saline $(0.1 \mathrm{ml} / 10 \mathrm{~g})$ at light onset as a control. On a separate day, VIP was administered at the same time of day at a dose of $0.3 \mu \mathrm{g} / \mathrm{g}$ in a volume of $10 \mu \mathrm{l} / \mathrm{g}$ body weight. An EEG and EMG were recorded for the next $23 \mathrm{~h}$.

Ether stress. The mice $[n=12(+/-), n=12(-/-)]$ were placed individually into a jar $(10 \mathrm{~L})$ containing ether vapor for $1 \mathrm{~min}(20 \mathrm{~min}$ before light onset) and then returned to their recording cage. A cotton cloth soaked with ether was in the bottom of the jar, and it was separated from the mouse via a plastic plate with holes. The lid of the jar was closed. The mice exhibited motor uncoordination near the end of the exposure, but they were still standing or rearing; anesthesia did not occur. As a control treatment, mice were placed in an identical jar that did not contain ether vapor. After ether exposure or control exposure, mice were recorded from for the next $23 \mathrm{~h}$.

\section{Determination of plasma $P R L$ bioactivity}

After $(-/-)$ mice receiving PRL or $(+/-)$ mice receiving saline were killed, trunk blood was taken to determine PRL bioactivity by means of the Nb2 lymphoma assay as described previously (Kacsóh et al., 1993; Kacsóh, 1997).

\section{Determination of hypothalamic mRNA by reverse transcription- $P C R$}

Mice were killed 2-4 h after light onset. Hypothalami were dissected from 12 heterozygous $(+/-)$ and 12 knock-out $(-/-)$ mice as described previously (Bohnet et al., 2004). Hypothalami from the $(-/-)$ and $(+/-)$ mice that received PRL replacement were also used. Total RNA was extracted by using Trizol reagent according to the manufacturer's protocol (Invitrogen, San Diego, CA). The RNAs were resuspended in RNase-free water and incubated with 2-4 U of DNase-RNase free and 1 $\mu \mathrm{l}$ of SuperRNase In (Ambion, Austin, TX) at $37^{\circ} \mathrm{C}$ for $1 \mathrm{~h}, 30 \mathrm{~min}$. RNA concentration was quantified by spectrophotometry at $260 \mathrm{~nm}$. RNA integrity was verified by electrophoresis run on an agarose denaturing gel and subsequent visualization.

The synthesis of first-stranded cDNA was described in detail previously (Bohnet et al., 2004; Chen et al., 2004). Briefly, aliquots of RNA (2 $\mu \mathrm{g} / 4 \mu \mathrm{l}), 1 \mu \mathrm{l}$ of oligodT, and $1 \mu \mathrm{l}$ of $10 \mathrm{~mm}$ deoxynucleoside triphosphates were incubated at $65^{\circ} \mathrm{C}$ for $5 \mathrm{~min}$. After chilling on ice, $200 \mathrm{U}$ of Superscripts III RNase H reverse transcriptase (Invitrogen), $1 \mu \mathrm{l}$ of $0.1 \mathrm{M}$ DTT, $1 \mu$ lof RNase inhibitor, and $4 \mu$ l of $5 \times$ cDNA synthesis buffer were added to a final volume of $20 \mu \mathrm{l}$ and incubated at $55^{\circ} \mathrm{C}$ for $60 \mathrm{~min}$. Then the mixture was heated at $70^{\circ} \mathrm{C}$ for $15 \mathrm{~min}$ and digested with $1 \mu \mathrm{l}$ of 
Table 1. Primers used for quantitative real-time, reversed-phase PCRs

\begin{tabular}{|c|c|c|c|}
\hline Gene & GenBank & Primer & Sequence $5^{\prime}-3^{\prime}$ \\
\hline \multirow[t]{2}{*}{ Orexin } & \multirow[t]{2}{*}{ NM_010410 } & Sense & GCCGTCTCTACGAACTGTTGC \\
\hline & & Antisense & CGCTTTCCCAGAGTCAGGATA \\
\hline \multirow{3}{*}{$\begin{array}{l}\text { Tyrosine } \\
\text { hydroxy- } \\
\text { lase }\end{array}$} & \multirow[t]{3}{*}{ NM_009377 } & Sense & CTTCCAATACAAGCAGGGTGAG \\
\hline & & Antisense & TCCTTCCAGGTAGCAATTTCC \\
\hline & & & \\
\hline \multirow[t]{2}{*}{ NOS-1 } & \multirow[t]{2}{*}{ NM_008712 } & Sense & GAAACTCTCGGAGGAGGATGC \\
\hline & & Antisense & CTCAGATCTAAGGCGGTTGGTC \\
\hline \multirow[t]{2}{*}{ NOS-2 } & \multirow[t]{2}{*}{ U43428 } & Sense & CAGGAAGAAATGCAGGAGATGG \\
\hline & & Antisense & GATGTCCTGAACGTAGACCTTGG \\
\hline \multirow[t]{2}{*}{ VIP } & \multirow[t]{2}{*}{ NM_011702 } & Sense & CCTCACTACAGAAGGTGGTCCAAAGAGAGGCC \\
\hline & & Antisense & GAAGCCAGAAGCAAGCCTCAGTTCCTGGCA \\
\hline \multirow[t]{2}{*}{$\mathrm{PRL}^{a}$} & \multirow[t]{2}{*}{ NM_011164 } & Sense & TGACTGCCAGACTTCTCTCCG \\
\hline & & Antisense & GACCATAAACTCACGGTCTTGC \\
\hline \multirow{2}{*}{$\begin{array}{l}\text { IFN type I } \\
\text { receptor }\end{array}$} & \multirow[t]{2}{*}{ NM_010508 } & Sense & GGCTAAATGTTGCAGGTTCC \\
\hline & & Antisense & ATTAAAGCGTGGCACCAGAT \\
\hline \multirow[t]{2}{*}{ Cyclophillin A } & \multirow[t]{2}{*}{ NM_008907 } & Sense & AAATGCTGGACCAACACAAAC \\
\hline & & Antisense & TTGATGCCTTCTTTCACCTTC \\
\hline
\end{tabular}

${ }^{a}$ The primers for PRL amplify a product in the $5^{\prime}$ region (161-290), and thus a product is amplified in the (-/-) mice (Horseman et al., 1997).

RNase $\mathrm{H}$ at $37^{\circ} \mathrm{C}$ for $20 \mathrm{~min}$. Finally, cDNA was cooled to room temperature and stored at $-20^{\circ} \mathrm{C}$ until additional analysis.

Real-time PCR was performed on an iCycler iQ Detection System (Bio-Rad, Hercules, CA) as described previously (Bohnet et al., 2004; Chen et al., 2004). The reaction mixture (25 $\mu \mathrm{l})$ contained $3 \mu$ l of diluted cDNA (6 ng), $12.5 \mu$ l of $2 \times$ Platinum Quantitative PCR SuperMix-UDG (Invitrogen), $0.25 \mu$ l each of SYBR Green (1:1000 dilution) and fluorescein (1:1000 dilution), and $0.5 \mu \mathrm{l}$ of forward and reverse primers at 10 $\mu \mathrm{M}$. Primers were designed using Primer3 (www.genome.wi.mit.edu/ cgi-bin/primer/primer3_www.cgi), and, if possible, an intron was spanned. A standard curve and efficiency analysis of the primers were performed, and the primer efficiencies were $>90 \%$. The primers used are listed in Table 1.

To activate uracil DNA glycosylase, the reactions were performed with one cycle at $50^{\circ} \mathrm{C}$ for $2 \mathrm{~min}$ and $95^{\circ} \mathrm{C}$ for $2 \mathrm{~min}$. The amplification was followed by 40 cycles of denaturation at $94^{\circ} \mathrm{C}$ for $15 \mathrm{~s}$, annealing at $58^{\circ} \mathrm{C}$ for $15 \mathrm{~s}$, and extension at $72^{\circ} \mathrm{C}$ for $15 \mathrm{~s}$. Finally, a melting curve was generated by stepwise increasing temperature $\left(0.5^{\circ} \mathrm{C}\right.$ increase every $\left.10 \mathrm{~s}\right)$ for 80 cycles starting at $55^{\circ} \mathrm{C}$. If multiple peaks were observed in meltcurve analysis, the data were not used. The threshold cycle $(\mathrm{Ct})$ was determined using SYBR Green fluorescence.

The real-time PCRs were performed in triplicate, and average values were reported as Ct values. The $\Delta \mathrm{Ct}$ values were determined by subtracting the reference cyclophillin A Ct values from the target gene Ct values. Relative gene expression was quantified with a comparative Ct method (User Bulletin \#2 ABI Prism 7700 sequence detection system; Applied Biosystems, Foster City, CA). The fold change between the mRNA expression levels of the experimental samples (knock-out mice) and the control samples (heterozygous mice) was calculated (Table 2).

\section{Statistical analyses}

For sleep parameters, two-way ANOVA was used to compare hourly values of NREMS, REMS, and EEG SWA among the various groups and between baseline and experimental days, when appropriate. The two factors of the ANOVA were time effects and treatment effects (or group effects-independent samples). If significant differences were indicated, the Bonferroni's (all-pairwise) multiple comparison test was used. PCR data were analyzed by Student's $t$ tests.

\section{Results}

\section{Spontaneous sleep}

Spontaneous NREMS was similar in all three groups [PRL $(+/+),(+/-)$, and $(-/-)]$ with no statistically significant differences (Fig. 1). In each group, NREMS was greater during daylight hours and lower during the night with a pronounced nadir of sleep at dark onset. The duration of REMS was similar between the wild-type mice $[(+/+)]$ and the heterozygous mice $[(+/-)]$. As with NREMS, REMS was greater during the daylight hours and less at night. The values of NREMS and REMS duration and their day-night distribution are similar to those reported previously for 129Sv mice (Bohnet et al., 2004), the background strain for the mice used. In contrast to these results, the duration of REMS in the PRL-deficient $(-/-)$ mice was significantly less $\left(F_{(1,18)}=28.47 ; p \ll 0.01\right)$ during the day time compared with those amounts observed in $(+/-)$ mice (Fig. 1, right). During the night, the duration of REMS was similar in the $(+/-)$ and $(-/-)$ mice. The EEG power spectra during REMS and NREMS in the $(+/-)$ mice was similar to that observed in the $(-/-)$ mice whether calculated during the sleep period (light) or for the entire $23 \mathrm{~h}$ recording period (Fig. 2 ).

\section{PRL replacement}

The duration of REMS was restored to $98.9 \%$ of $(+/-)$ mice in those $(-/-)$ mice that received PRL replacement for $10-11 \mathrm{~d}$ before recordings (Fig. 3). Thus, PRL replacement significantly increased REMS during the daylight hours in the $(-/-)$ mice $\left(F_{(1,14)}=25.34 ; p<0.01\right)$. These mice did not exhibit increases in REMS during dark hours, nor was their NREMS affected by this treatment. Heterozygous mice $[(+/-)]$ receiving saline did not alter their sleep patterns from the baseline conditions (data not shown).

\section{SD}

In $(+/-)$ mice, after $6 \mathrm{~h}$ of $\mathrm{SD}$, there was an increase in the duration of REMS $\left(F_{(1,18)}=14.39 ; p<0.01\right)$ and NREMS $\left(F_{(1,18)}=12.70 ; p<0.01\right)$ during the remaining hours of the light period (Fig. 4). In the subsequent dark period, these $(+/-)$ mice had NREMS values similar to those obtained from the same mice under control conditions $\left(F_{(1,18)}=1.38 ; p<0.25\right)$. In contrast, in the $(+/-)$ mice, REMS increased in the dark period after SD $\left(F_{(1,18)}=6.86 ; p<0.02\right)$.

In $(-/-)$ mice, $6 \mathrm{~h}$ of sleep loss also induced an increase in the duration of NREMS in the light period immediately after the deprivation period $\left(F_{(1,18)}=12.35 ; p<0.01\right)$, but this increase did not extend into the dark period $\left(F_{(1,8)}=0.40 ; p>0.05\right)$. SD of $(-/-)$ mice also induced an increase in REMS in the light period $\left(F_{(1,18)}=5.68 ; p<0.05\right)$ but not in the subsequent dark period $\left(F_{(1,18)}=0.01 ; p>0.9\right)$. Averaged for the $17 \mathrm{~h}$ immediately after sleep loss, $(+/-)$ mice increased REMS by $21 \mathrm{~min}$ $\left(F_{(1,18)}=15.69 ; p<0.01\right)$, whereas the $(-/-)$ mice only increased REMS by $8 \min \left(F_{(1,18)}=1.34 ; p>0.25\right)$ above the amount of REMS that occurred during control conditions (57 vs $43 \mathrm{~min}$, respectively). In a direct comparison of the amount of REMS occurring in $(+/-)$ and $(-/-)$ mice, there was significantly less REMS in the $(-/-)$ mice after deprivation in hours $7-23$ (Fig. 4) than in $(+/-)$ mice $\left(F_{(1,16)}=18.13 ; p<0.003\right)$.

EEG SWA during NREMS increased in both $(+/-)$ and $(-/-)$ mice in the first $4-6 \mathrm{~h}$ after sleep loss. After that, EEG SWA decreased compared with control values (Fig. 4). These responses were similar in both $(+/-)$ and $(-/-)$ mice.

\section{VIP treatment}

VIP induced significant increases in REMS in the $(+/-)$ mice during the daylight hours (treatment: $F_{(1,11)}=6.334, p<0.05$; interaction: $\left.F_{(11,121)}=2.882, p<0.05\right)$. VIP had no significant effect on duration of REMS in the subsequent dark period in the $(+/-)$ mice, nor did it alter the duration of NREMS in these mice. In contrast, in $(-/-)$ mice, VIP failed to affect the duration 
Table 2. Hypothalamic mRNA levels in heterozygous $[(+/-)]$ and homozygous $[(-/-)]$ mutant mice lacking PRL and in $(-/-)$ mice receiving PRL and (+/-) mice receiving saline

\begin{tabular}{llllllll}
\hline $\begin{array}{l}\text { Spontaneous difference } \\
\text { (fold increase) }\end{array}$ & Orexin & Tyrosine hydroxylase & NOS-1 & NOS-2 & VIP & PRL & Interferon type I receptor \\
\hline$(-/-)$ & $0.92 \pm 0.042^{a}$ & $0.77 \pm 0.54$ & $0.98 \pm 0.297$ & $0.85 \pm 0.106$ & $0.89 \pm 0.106$ & $4.45 \pm 1.797$ & $0.92 \pm 0.042$ \\
$(+/-)$ & $1.01 \pm 0.050$ & $1.05 \pm 0.109$ & $1.03 \pm 0.071$ & $1.08 \pm 0.145$ & $1.04 \pm 0.086$ & $2.67 \pm 1.288^{a}$ & $1.01 \pm 0.050$ \\
$p$ & 0.141 & $0.028^{*}$ & 0.622 & 0.153 & 0.262 & 0.411 & 0.141 \\
\hline $\begin{array}{l}\text { Fold increase after PRL } \\
\text { replacement }\end{array}$ & Orexin & Tyrosine hydroxylase & NOS-1 & NOS-2 & VIP & PRL & Interferon type I receptor \\
\hline$(-/-)$ & $0.97 \pm 0.094$ & $1.29 \pm 0.170$ & $1.03 \pm 0.051$ & $1.04 \pm 0.069$ & $0.63 \pm 0.103$ & $5.22 \pm 2.047$ & $1.17 \pm 0.63$ \\
$(+/-)$ & $1.05 \pm 0.106$ & $1.12 \pm 0.176$ & $1.05 \pm 0.093$ & $1.03 \pm 0.083$ & $1.05 \pm 0.109$ & $1.30 \pm 0.486$ & $1.05 \pm 0.100$ \\
$p$ & 0.573 & 0.481 & 0.860 & 0.936 & $0.008^{*}$ & 0.096 & 0.289 \\
\hline
\end{tabular}

${ }^{a}$ Values are $\Delta \Delta$ Ct values (see Materials and Methods) \pm SEM. Variance in the PRL values was high, therefore values for $(+/-)$ mice are not close to 1.0 . ${ }^{*} p<0.05$.
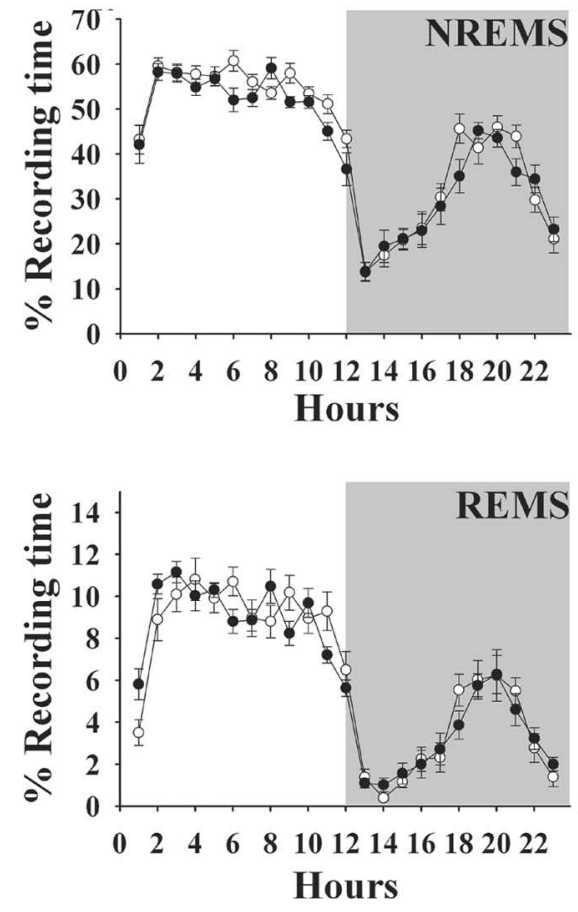

Figure 1. Comparison of sleep patterns between wild-type $(n=10 ; \bigcirc)$ and heterozygous $(n=12 ; \bigcirc)$ (left graphs) littermates and between heterozygous mice $(n=11 ; \bigcirc)$ and PRL knock-out mice $(n=10 ; 0)$ (right graphs). The top graphs show the percentage of time spent in NREMS, and the bottom graphs show the percentage of time spent in REMS. Sleep duration and its distribution across the day-night cycle were similar in the wild-type and heterozygous mice. In contrast, PRL knock-out mice had substantially less REMS, although day-night differences persisted. Means \pm SEM are shown. The asterisks indicate significant difference $(p<0.05$; post hoc test).

of REMS during the daylight or night hours, nor did it alter NREMS (Fig. 5).

\section{Ether stress}

Ether stress enhanced duration of REMS during the daylight hours immediately after exposure in the $(+/-)$ mice (treatment: $\left.F_{(1,11)}=11.479 ; p<0.01\right)$. The increases in REMS became manifest $\sim 4 \mathrm{~h}$ after exposure to ether and persisted for approximately another $8 \mathrm{~h}$. In the subsequent dark period, REMS was near control values. Ether stress did not affect duration of NREMS. In the $(-/-)$ mice, the ether stressor failed to affect any parameters of sleep. Thus, duration of REMS in the $(-/-)$ mice was less than that observed in the $(+/-)$ mice, but it did not increase after ether vapor exposure (Fig. 6).
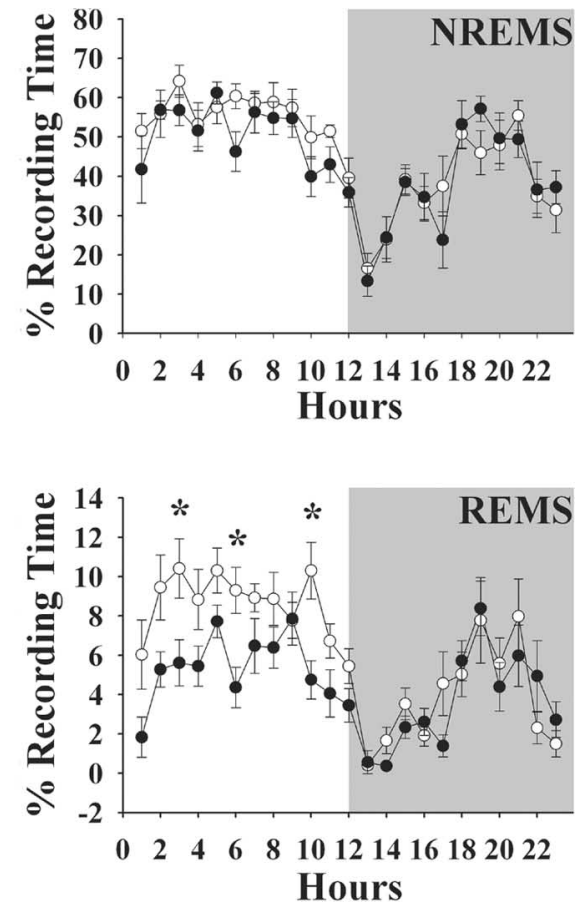

Hypothalamic gene expression

There were no differences in mRNA levels between $(+/-)$ and $(-/-)$ mice for orexin, nitric oxide synthase 1 (NOS-1), NOS-2, VIP, PRL, and the interferon type I receptor; all of these substances are implicated in REMS regulation (Table 1). In contrast, tyrosine hydroxylase mRNA, the enzyme needed for dopamine synthesis, was significantly less in the $(-/-)$ mice compared with the $(+/-)$ mice. After PRL replacement in $(-/-)$ mice, tyrosine hydroxylase mRNA was not significantly different from that observed in $(+/-)$ mice, although after this treatment, VIP mRNA significantly decreased in the $(-/-)$ mice.

\section{Discussion}

The major finding reported here is that PRL-deficient mice have less spontaneous REMS during the daylight hours than wild-type or heterozygous littermates. Furthermore, PRL replacement in the $(-/-)$ mice results in REMS indistinguishable from that observed in heterozygous littermates. These data suggest a role for PRL in REMS regulation and are consistent with previous data that demonstrate the REMS-promoting activity of acute administration of PRL (Obál et al., 1989; Roky et al., 1993, 1994) and the excess REMS in rats rendered chronically hyperprolactinemic by means of pituitary grafts (Obál et al., 1997). In contrast, a hypoprolactinemic mutant rat strain exhibited increases in REMS with more REMS during the dark phase than in the light phase (Lobo et al., 1999). These rats have an altered sensitivity to photo-enhancement signals as well as other deficits such as being hairless, and thus it is not possible to directly link their changes in REMS to reduced PRL levels. However, in the male PRL knock-out mice used in the current study, there are no known deficits other than the lack of functional PRL and reduced REMS duration reported here.

Although previous observations suggested a REMSpromoting activity for PRL, it was not clear whether PRL was involved in the REMS rebound after sleep loss. Current results clearly indicate that PRL-deficient mice exhibit a REMS rebound, although it is attenuated compared with heterozygous mice. This 


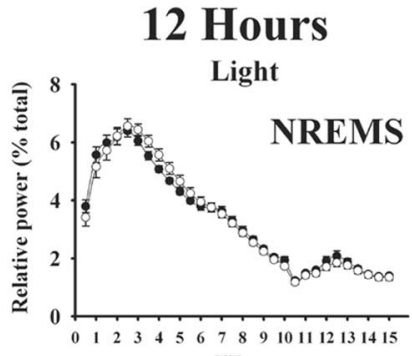

$\mathrm{Hz}$

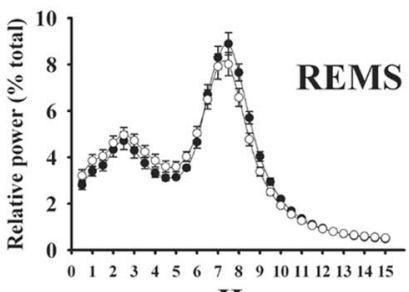

$\mathrm{Hz}$

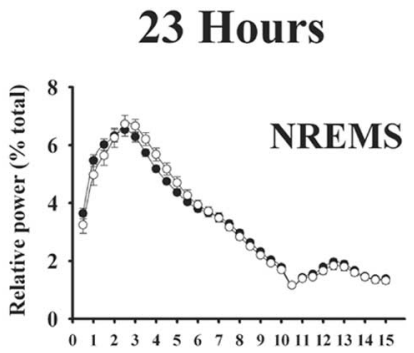

$\mathrm{Hz}$

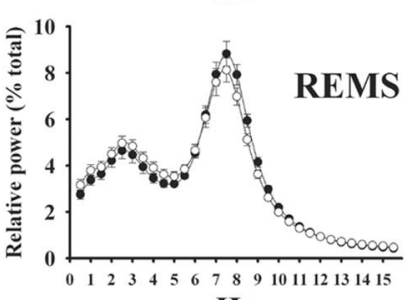

$\mathrm{Hz}$

Figure 2. Relative EEG power (squared microvolts) expressed as a percentage of total power in heterozygous $[(+/-) ; \bigcirc]$ and PRL knock-out $[(-/-)$; $]$ mice during the $12 \mathrm{~h} \mathrm{light}$ period (left graphs) and the entire $23 \mathrm{~h}$ recording period (right graphs). The top graphs show relative EEG power during NREMS; characteristic patterns were observed in both $(+/-)$ and $(-/-)$ mice, with the greatest power in the low-frequency ranges. The bottom graphs show relative EEG power during REMS; both groups of mice exhibited the theta peak characteristic of REMS. There were no differences between $(+/-)$ and $(-/-)$ mice. Values are means \pm SEM.

suggests that PRL may enhance a REMS-promoting mechanism rather than be an initiator of REMS.

Jouvet (1994) suggested that stimulation of pyruvate dehydrogenase $(\mathrm{PDH})$ in mesencephalic/pontine cholinergic neurons may serve as a final common pathway for various interventions that promote REMS. PRL stimulates PDH activity in the prostate (Costello et al., 1995) and the mammary gland (Waters and Rillema, 1988). Enhanced PDH activity results in increased acetylcoenzyme A and thereby stimulates the synthesis of acetylcholine (ACh). PDH is particularly enriched in cholinergic neurons (Milner et al., 1987; Rozanov and Parkhomenko, 1987). Furthermore, brain cholinergic neurons are vulnerable to the deficiency of PDH (Ruenwongsa and Pattenavibag, 1984). ACh levels are decreased by the PDH inhibitor 3-bromopyruvate in brain homogenates or in the basal forebrain after local injection of this compound (Arendt et al., 1990). Decreases in PDH activity elicited by experimental thiamine deficiency, are also associated with the suppression of REMS; thiamine is a coenzyme for PDH (Crespi and Jouvet, 1982). We propose that because PRL stimulates PDH in cholinergic neurons whenever spontaneous REMS occurs via cholinergic neurons, the quantity of ACh released increases, thereby facilitating spontaneous REMS but not initiating it. There is thus no need to assume that PRL acts via the suprachiasmatic nucleus on REMS as suggested previously by Roky et al. (1993, 1994). PRL is more effective in stimulating REMS during the light period than at night, simply because more spontaneous REMS occurs during the light than during the dark period.

Intracerebral administration of PRL or antibodies to PRL stimulates or inhibits REMS, respectively (Roky et al., 1993, 1994), suggesting a central action of PRL. PRL has several sources, including hypothalamic and brainstem neurons (BoleFeysot et al., 1998; Freeman et al., 2000; Bohnet et al., 2004; Chen et al., 2004) and the anterior pituitary. Circulating PRL is transported into the brain via the choroid plexus (Walsh et al., 1987), and circulating PRL promotes REMS. Thus, systemically injected PRL (Jouvet et al., 1986; Obál et al., 1989), excess PRL released

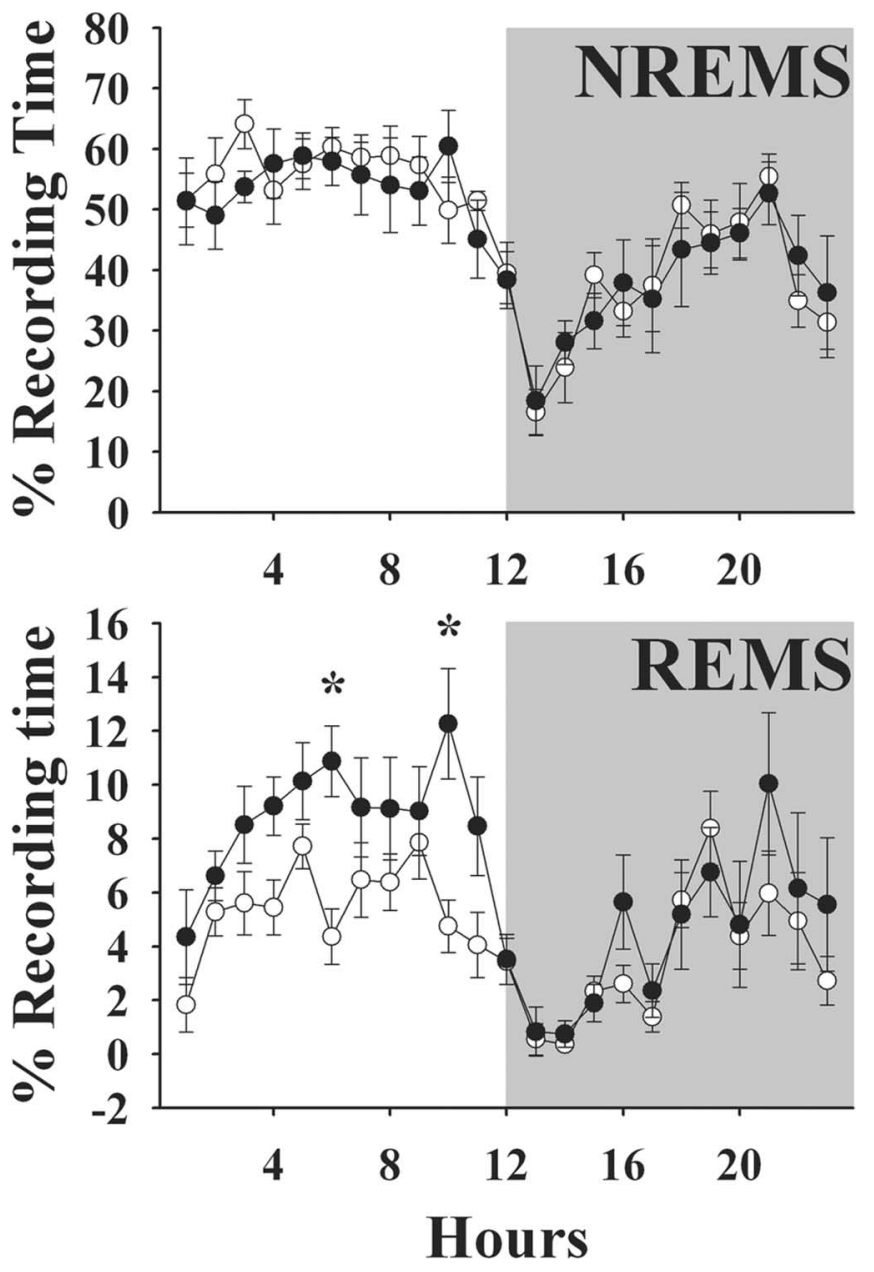

Figure 3. $P R L$ replacement in PRL knock-out mice restores REMS. PRL was provided to PRL $(-/-)$ mice via a mini-osmotic pump for $11-12 \mathrm{~d}$ before recordings were done $(O)$. Values from $(-/-)$ knock-out mice $(\bigcirc)$ are those from the mice shown in Figure 1 (right graphs). PRL replacement had no effect on the duration or diurnal distribution of NREMS; it did, however, enhance REMS during daylight hours in the $(-/-)$ mice. Means \pm SEM are shown. The asterisks indicate significant difference ( $p<0.05$; post hoc test).

from pituitary grafts (Obál et al., 1997), or stimulation of endogenous PRL secretion from the pituitary (Obál et al., 1994) all promote REMS. Nevertheless, only slight decreases in REMS are observed when basal, nonstimulated circulating PRL is immunoneutralized (Obál et al., 1992). Although plasma PRL levels in humans are sleep related and highest in the early morning hours, patients with PRL-producing adenomas fail to display changes in REMS (Frieboes et al., 1998).

Hypothalamic PRL-containing neurons may innervate various structures in the brain including the brainstem (Paut-Pagano et al., 1993). However, the anti-ovine PRL antibody used in those rat studies also recognizes hypocretin (orexin), thereby suggesting that lateral hypothalamic immunoreactive prolactinergic neurons may, in fact, be hypocretinergic neurons (Risold et al., 1999). Regardless, the site of action where PRL modulates REMS is not clear. Indeed, when injected into the central amygdalar nucleus, PRL fails to affect REMS but inhibits NREMS (Sanford et al., 1998). Valatx et al. (1990) and Roky et al. (1994) suggest that PRL interferes with regulation of the diurnal rhythm of REMS, perhaps via PRL receptors in the suprachiasmatic nucleus. Their hypothesis, however, disregards the observation that PRL enhances REMS in pontine cats (Jouvet et al., 1986), and it 

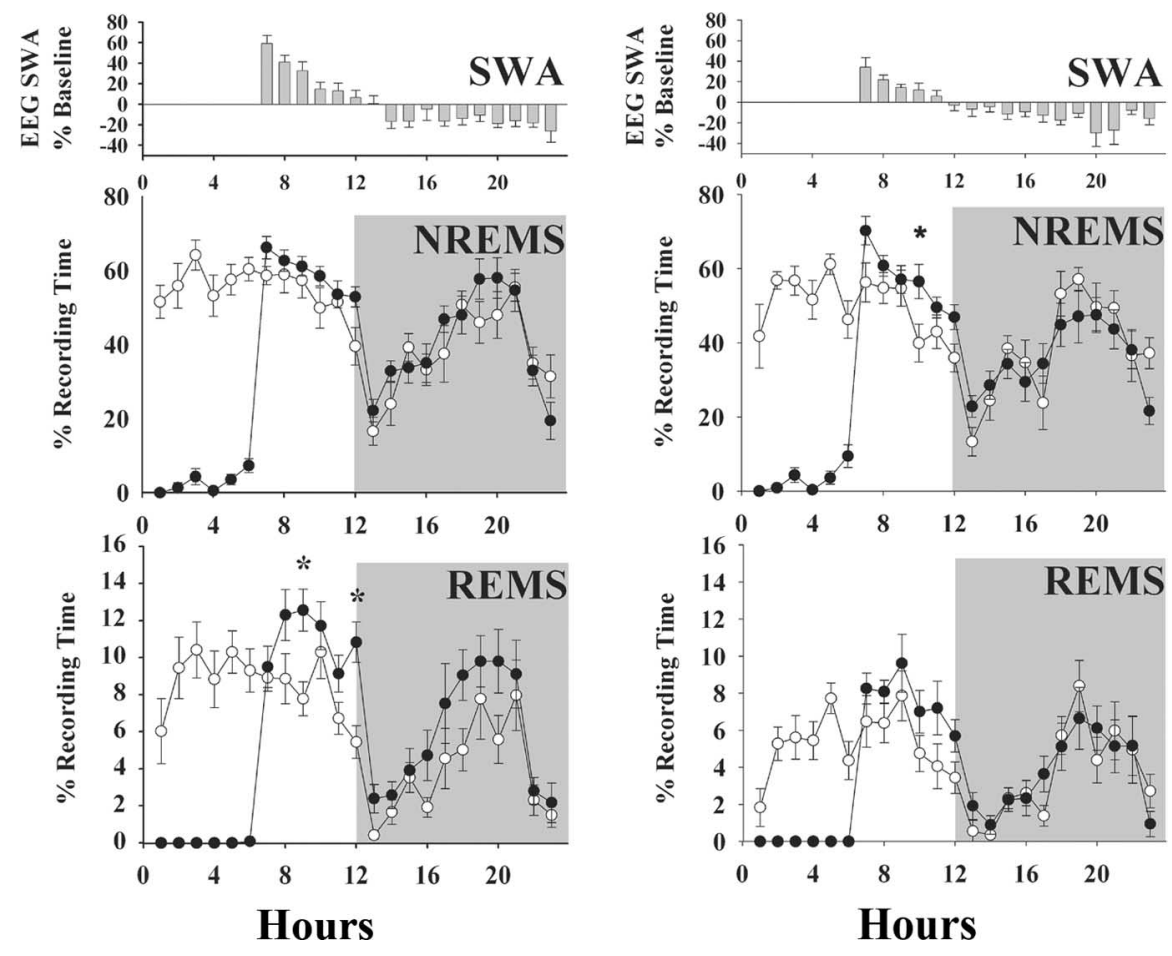

Figure 4. SD ( $6 \mathrm{~h}$ beginning at time 0$)$ of heterozygous [ $(+/-)$; left graphs $]$ and PRL knock-out $[(-/-)$; right graphs] mice induces NREMS and REMS rebounds in both types of mice. The extent and timing of the NREMS rebound was similar in both $(+/-)$ and $(-/-)$ mice. However, the REMS rebound was limited to daylight hours, and its magnitude was less in the $(-/-)$ mice compared with littermates $[(+/-)$ mice]. Values are means \pm SEM from a baseline control day $(\bigcirc)$ and the SD day $(\boldsymbol{O})$. EEG SWA responses were similar in both sets of mice and were characteristic of that seen in other mice and rats initially characterized by an enhancement then followed by a decrease in EEG SWA. The asterisks indicate significant difference $(p<0.05 ; p 0 s t$ hoc test).
Het
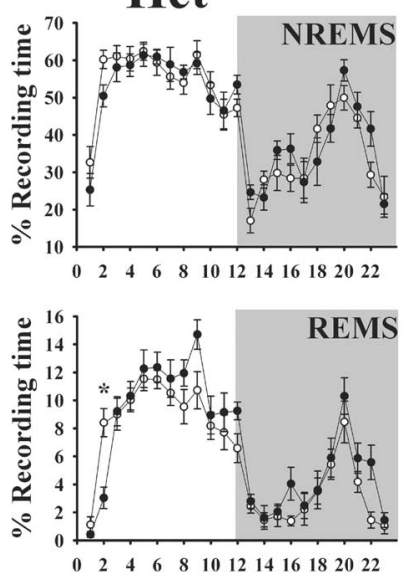

Hours
KO
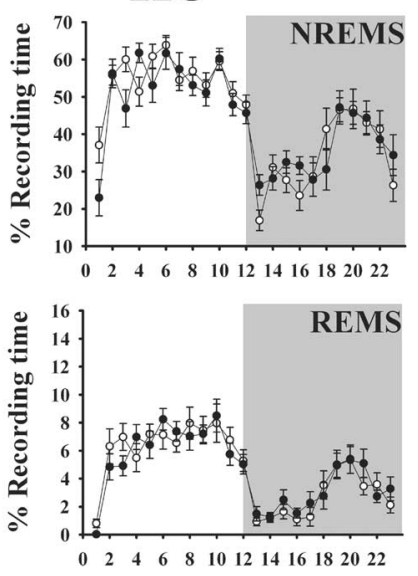

Hours
Figure 5. VIP enhances REMS in heterozygous mice [Het; $(+/-)$; left graphs] but not in PRL knock-out mice [KO; $(-/-)$; right graphs]. VIP $(0.3 \mu \mathrm{g} / \mathrm{g}$ body weight) was injected intraperitoneally at light onset (time 0 ). The mice used for these experiments were different from those used in other experiments; the lowered spontaneous REMS in the $(-/-)$ mice is evident by comparing the right and left graphs. $\bigcirc$, Control values; $\bigcirc$, values obtained after VIP. Values are means \pm SEM. The asterisks indicate significant difference $(p<0.05$; post hoc test).

does not consider subsequent evidence suggesting a brainstem PRL-nitric oxide (NO) interaction (Chen et al., 2004). PRL immunoreactivity, PRL mRNA, and PRL receptor mRNA are found in the brainstem (Harlan et al., 1989; Siaud et al., 1989; Freemark et al., 1995; Bole-Feysot et al., 1998). Therefore, we prefer a mech- anism involving the brainstem cholinergic REMS-promoting mechanism, although the cellular origins of brainstem PRL and PRL receptors remain unknown.

Inbred mouse strains display significant variations in the EEG, particularly in the theta peak frequency, during both REMS and NREMS, suggesting the presence of genes influencing theta activity (Franken et al., 1998; Tafti et al., 2003). For instance, deficiency in the gene of the short-chain acyl-coenzyme A dehydrogenase (Acads) results in slowing of theta activity during REMS (Tafti et al., 2003). Nevertheless, the PRL-deficient mice used in this study exhibited a normal EEG power spectrum, suggesting that PRL is not directly involved in those mechanisms responsible for EEG power. This conclusion is consistent with the indirect role proposed above for PRL involvement in REMS regulation.

PRL-induced NO might be part of the REMS-promoting activity of PRL. There is involvement of NOergic neurons in the laterodorsal tegmental and pedunculo tegmental nuclei (LDT/PPT) in REMS regulation. PRL excites LDT neurons (Takahashi et al., 2000), and LDT neuron activation increases NO production and elevates extracellular NO (Leonard et al., 2001). PRL induces inducible NOS (iNOS) mRNA in glioma cells in vitro (Raso et al., 1999) and neuronal NOS (nNOS) protein expression in neurons in the paraventricular and supraoptic nuclei in vivo (Popeski et al., 2003). PRL receptor activation upregulates the expression of nNOS protein in $\mathrm{GH}_{3}$ rat pituitary adenoma cells (Secondo et al., 2003). PRL also increases NO production in other cell types [e.g., immune cells (Kumar et al., 1997; Meli et al., 1997) and epithelial cells (Bolander 2002]. NO reduces intracellular calcium through cGMP (Esplugues, 2002) and modulates cAMP signaling (Klein, 2002). The reduction in intracellular calcium or cAMP levels inhibits PRL gene expression in pituitary cells (Liu et al., 2002). Thus, NO may also form a feedback loop to inhibit PRL when the source of NO is close to PRL-containing cells.

We failed to observe differences in either iNOS or nNOS mRNA levels in the hypothalamus. We also failed to observe differences in mRNAs of other substances linked previously to REMS regulation, including hypothalamic VIP, interferon type I receptor, and PRL mRNAs. Such data are consistent with the notion that the actions of PRL on REMS are indirect, involving perhaps the brainstem $\mathrm{PDH}-\mathrm{ACh}$ mechanism mentioned above. In contrast to these negative findings, the levels of tyrosine hydroxylase mRNA decreased in the $(-/-)$ mice compared with their $(+/-)$ littermates. Tyrosine hydroxylase is an enzyme involved in dopamine synthesis. Pituitary PRL release is under a continuous dopamine inhibition. Because the $(-/-)$ mice are not producing functional PRL, there is a reduced need to inhibit pituitary release of PRL, and this is manifest as a reduced level of hypothalamus tyrosine hydroxylase. This observation is consistent with the established short-loop negative feedback regulation of PRL (Perkins et al., 1979; Reymond, 1990)

The lack of an effect of ether vapor exposure on REMS in the 

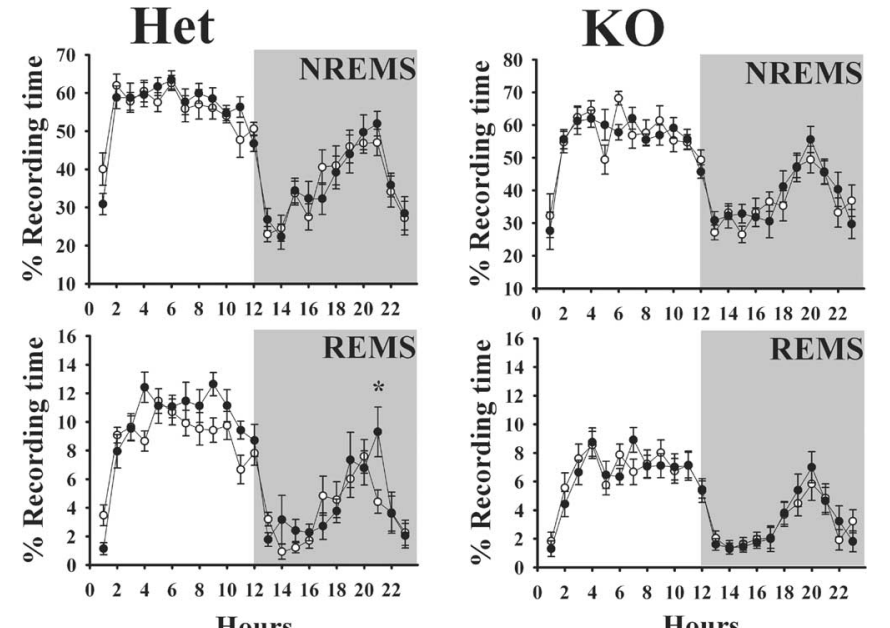

Hours

Figure 6. Ether stress enhances REMS in heterozygous mice [Het; $(+/-)$; left graphs] but not in PRL knock-out mice [K0; $(-/-)$; right graphs]. Mice were exposed to ether vapors for $\sim 1$ min during the last 20 min of the dark period (light onset; time 0 ). Ether stress did not affect NREMS. The mice used for these experiments were different from those used in other experiments. Spontaneous sleep values again illustrate that $(-/-)$ mice have less REMS than littermate $[(+/-)]$ mice. $\bigcirc$, Control values; $\boldsymbol{O}$,values obtained after ether stress. Values are means \pm SEM. The asterisks indicate significant difference $(p<0.05$; post hoc test).

$(-/-)$ mice is consistent with the notion that stressor-enhanced REMS is mediated in part via PRL. Restraint stress and ether stress are associated with enhanced circulating PRL and enhanced REMS (Bodosi et al., 2000; Meerlo et al., 2001). Restraint stress also enhances hypothalamic release of PRL (Torner et al., 2004), although stressor-induced release of pituitary PRL is thought to be responsible for the increases in REMS after stress (Bodosi et al., 2000; Meerlo et al., 2001).

In conclusion, data reported here suggest that PRL plays a role in the regulation of spontaneous REMS and REMS responses to SD, systemic VIP, and an ether stressor. These and other data also suggest that these REMS-promoting actions of PRL are indirect, perhaps operating via a brainstem LPT/PPT-PDH cholinergic NO mechanism.

\section{References}

Arendt T, Schugens MM, Marchbanks RM (1990) Reversible inhibition of acetylcholine synthesis and behavioral effects caused by 3-bromopyruvate. J Neurochem 55:1474-1479.

Bodosi B, Obál Jr F, Gardi J, Komlódi J, Fang J, Krueger JM (2000) An ether stressor increases REM sleep in rats: possible role of prolactin. Am J Physiol 279:R1590-R1598.

Bohnet SG, Traynor TR, Majde JA, Kacsóh B, Krueger JM (2004) Mice deficient in the interferon type I receptor have reduced REM sleep and altered hypothalamic orexin, prolactin and $2^{\prime}, 5^{\prime}$-oligoodenylate synthatase expression. Brain Res 1027:117-125.

Bolander Jr FF (2002) Prolactin activation of mammary nitric oxide synthase: molecular mechanisms. J Mol Endocrinol 28:45-51.

Bole-Feysot C, Goffin V, Edery M, Binart N, Kelly PA (1998) Prolactin (PRL) and its receptor: actions, signal transduction pathways and phenotypes observed in PRL receptor knockout mice. Endocr Rev 19:225-268.

Chen L, Taishi P, Duricka D, Krueger JM (2004) Brainstem prolactin mRNA is enhanced in mice with suppressed neuronal nitric oxide synthase activity. Mol Brain Res 129:179-184.

Costello LC, Liu Y, Franklin RB (1995) Prolactin specifically increases pyruvate dehydrogenase $\mathrm{E} 1 \alpha$ in rat lateral prostate epithelial cells. Prostate 26:189-193.

Crespi F, Jouvet M (1982) Sleep and indolamine alterations induced by thiamine deficiency. Brain Res 248:275-283.

Esplugues JV (2002) NO as a signaling molecule in the nervous system. Br J Pharmacol 135:1079-1095.
Fang J, Payne L, Krueger JM (1995) Pituitary adenylate activating polypeptide enhances rapid eye movement sleep in rats. Brain Res 686:23-28.

Franken P, Malafosse A, Tafti M (1998) Genetic variations in EEG activity during sleep in inbred mice. Am J Physiol 275:R1127-R1137.

Freeman ME, Kanyicska B, Lerant A, Nagy G (2000) Prolactin: structure, function, and regulation of secretion. Physiol Rev 80:1523-1631.

Freemark M, Nagano M, Edery M, Kelly PA (1995) Prolactin receptor gene expression in the fetal rat. J Endocrinol 144:285-292.

Frieboes RM, Murck H, Stalla GK, Antonijevic IA, Steiger A (1998) Enhanced slow wave sleep in patients with prolactinoma. J Clin Endocrinol Metab 83:2706-2710.

Harlan RE, Shivers BD, Fox SR, Kaplove KA, Schachter BS, Pfaff DW (1989) Distribution and partial characterization of immunoreactive prolactin in the rat brain. Neuroendocrinology 49:7-22.

Horseman ND, Zhao W, Montecino-Rodriguez E, Tanaka M, Nakashima K, Engle SJ, Smith F, Markoff E, Dorshkind K (1997) Defective mammopoiesis, but normal hematopoiesis, in mice with a targeted disruption of the prolactin gene. EMBO J 16:6926-6935.

Jouvet M (1994) Paradoxical sleep mechanisms. Sleep 17:S77-S83.

Jouvet M, Buda C, Cespuglio R, Chastrette N, Denoyer M, Sallanon M, Sastre JP (1986) Hypnogenic effects of some hypothalamo-pituitary peptides. Clin Neuropharmacol 9 [Suppl 4]:465-467.

Kacsóh B (1997) Prolactin-like biological activity in the pituitary glands of the marsupial Monodelphis domestica and of the amphibian Rana pipiens detected by colorimetric $\mathrm{Nb} 2$ lymphoma cell proliferation assay. Proc Soc Exp Biol Med 214:146-155.

Kacsóh B, Veress Z, Toth BE, Avery LM, Grosvenor CE (1993) Bioactive and immunoreactive variants of prolactin in milk and serum of lactating rats and their pups. J Endocrinol 138:243-257.

Klein C (2002) Nitric oxide and the other cyclic nucleotide. Cell Signal 14:493-498.

Krueger JM, Obál Jr F, Opp M, Toth L, Johannsen L, Cady AB (1990) Somnogenic cytokines and models concerning their effects on sleep. Yale J Biol Med 63:157-172.

Kumar A, Singh SM, Sodhi A (1997) Effect of prolactin on nitric oxide and interleukin-1 production of murine peritoneal macrophages: role of $\mathrm{Ca}^{2+}$ and protein kinase C. Int J Immunopharmacol 19:129-133.

Leonard CS, Michaelis EK, Mitchell KM (2001) Activity-dependent nitric oxide concentration dynamics in the laterodorsal tegmental nucleus in vitro. J Neurophysiol 86:2159-2172.

Liu JC, Baker RE, Sun C, Sundmark VC, Elsholtz HP (2002) Activation of Go-coupled dopamine D2 receptors inhibits ERK1/ERK2 in pituitary cells. A key step in the transcriptional suppression of the prolactin gene. J Biol Chem 277:35819-35825.

Lobo LL, Claustrat B, Debilly G, Paut-Pagano L, Jouvet M, Valatx JL (1999) Hypoprolactinemic rats under conditions of constant darkness or constant light. Effects on the sleep-wake cycle, cerebral temperature and sulfatoxymelatonin levels. Brain Res 835:282-289.

Meerlo P, Easton A, Bergmann BM, Turek FW (2001) Restraint increases prolactin and REM sleep in C57BL/6J mice but not in BALB/cJ mice. Am J Physiol Regul Integr Comp Physiol 281:R846-R854.

Meli R, Raso GM, Gualillo O, Pacilio M, Di Carlo R (1997) Prolactin modulation of nitric oxide and TNF-alpha production by peripheral neutrophils in rats. Life Sci 61:1395-1403.

Milner TA, Aoki C, Sheu KF, Blass JP, Pickel VM (1987) Light microscopic immunocytochemical localization of pyruvate dehydrogenase complex in rat brain: topographical distribution and relation to cholinergic and catecholaminergic nuclei. J Neurosci 7:3171-3190.

Morrow JD, Opp MR (2005) Diurnal variation of lipopolysaccharideinduced alterations in sleep and body temperature of interleukin-6deficient mice. Brain Behav Immun 19:40-51.

Obál Jr F, Krueger JM (2000) Hormones, cytokines and sleep. In: Coping with the environment neural and endocrine mechanisms: handbook of physiology, Chap 16 (McEwen BS, ed), pp 331-349. New York: Oxford UP.

Obál Jr F, Sary G, Alföldi P, Rubicsek G (1986) Vasoactive intestinal polypeptide promotes sleep without effects on brain temperature in rats at night. Neurosci Lett 64:236-240.

Obál Jr F, Opp M, Cady AA, Johannsen L, Krueger JM (1989) Prolactin, vasoactive intestinal peptide, and peptide histidine methionine elicit selective increases in REM sleep in rabbits. Brain Res 490:292-300. 
Obál Jr F, Kacsóh B, Alfoldi P, Payne L, Markovic O, Grosvenor C, Krueger JM (1992) Antiserum to prolactin decreases rapid eye movement sleep (REM sleep) in the male rat. Physiol Behav 52:1063-1968.

Obál Jr F, Payne L, Kacsóh B, Opp M, Kapás L, Grosvenor CE, Krueger JM (1994) Involvement of prolactin in the REM sleep-promoting activity of systemic vasoactive intestinal peptide (VIP). Brain Res 645:143-149.

Obál Jr F, Kacsóh B, Bredow S, Guha-Thakurta N, Krueger JM (1997) Sleep in rats rendered chronically hyperprolactinemic with anterior pituitary grafts. Brain Res 755:130-136.

Paut-Pagano L, Roky R, Valatx JL, Kiatahama K, Jouvet M (1993) Anatomical distribution of prolactin-like immunoreactivity in the rat brain. Neuroendocrinology 58:682-695.

Perkins NA, Westfall TC, Paul CV, MacLeod R, Rogol AD (1979) Effect of prolactin on dopamine synthesis in medial basal hypothalamus: evidence for a short loop feedback. Brain Res 160:431-444.

Popeski N, Amir S, Diorio J, Woodside B (2003) Prolactin and oxytocin interaction in the paraventricular and supraoptic nuclei: effects on oxytocin mRNA and nitric oxide synthase. J Neuroendocrinol 15:687-696.

Raso GM, Meli R, Gualillo O, Pacilio M, Di Carlo R (1999) Prolactin induction of nitric oxide synthase in rat C6 glioma cells. J Neurochem 73:2272-2277.

Reymond MJ (1990) Age-related loss of the responsiveness of the tuberoinfundibular dopaminergic neurons to prolactin in the female rat. Neuroendocrinology 52:490-496.

Risold PY, Griffond B, Kilduff TS, Sutcliffe JG, Fellmann D (1999) Preprohypocretin (orexin) and prolactin-like immunoreactivity coexpressed by neurons of the rat lateral hypothalamic area. Neurosci Lett 259:153-156.

Roky R, Valatx JL, Jouvet M (1993) Effect of prolactin on the sleep-wake cycle in the rat. Neurosci Lett 156:117-120.

Roky R, Valatx JL, Paut-Pagano L, Jouvet M (1994) Hypothalamic injection of prolactin or its antibody alters the rat sleep-wake cycle. Physiol Behav 55:1015-1019.

Roky R, Obál Jr F, Valatx JL, Bredow S, Fang J, Pagano LP, Krueger JM (1995) Prolactin and rapid eye movement sleep regulation. Sleep 18:536-542.

Rozanov VA, Parkhomenko IuM (1987) Activity of pyruvate- and ketoglu- tarate dehydrogenase complexes on various regions of the rat brain. $\mathrm{Ukr}$ Biokhim Zh 59:29-34.

Ruenwongsa P, Pattenavibag S (1984) Impairment of acetylcholine synthesis in thiamine deficient rats developed by prolonged tea consumption. Life Sci 23:365-370.

Sanford LD, Nassar P, Ross RJ, Schulkin J, Morrison AR (1998) Prolactin microinjections into the amygdalar central nucleus lead to decreased NREM sleep. Sleep Res Online 1:109-113.

Secondo A, Sirabella R, Formisano L, D’Alessio A, Castaldo P, Amoroso S, Ingleton P, Di Renzo G, Annunziato L (2003) Involvement of PI3'-K, mitogen-activated protein kinase and protein kinase $\mathrm{B}$ in the upregulation of the expression of nNOSalpha and nNOSbeta splicing variants induced by PRL-receptor activation in GH3 cells. J Neurochem 84:1367-1377.

Siaud P, Manzoni O, Balmefrezol M, Barbanel G, Assenmacher I, Alonso G (1989) The organization of prolactin-like-immunoreactive neurons in the rat central nervous system. Light- and electron-microscopic immunocytochemical studies. Cell Tissue Res 255:107-115.

Tafti M, Petit B, Chollet D, Neidhart E, De Bilbao F, Kiss JZ, Wood PA, Franken P (2003) Deficiency in short-chain fatty acid $\beta$-oxidation affects theta oscillations during sleep. Nat Genet 34:325.

Takahashi K, Koyama Y, Kayama Y, Yamamoto M (2000) The effects of prolactin on the mesopontine tegmental neurons. Psychiatry Clin Neurosci 54:257-258.

Torner L, Maloumby R, Nava G, Aranda J, Clapp C, Neumann ID (2004) In vivo release and gene upregulation of brain prolactin in response to physiological stimuli. Eur J Neurosci 19:1601-1608.

Valatx JL, Roky R, Paut-Pagano L (1990) Prolactin and sleep regulation. In: Sleep '90 (Horne J, ed), pp 346-348. Bochum, Germany: Pontenagel.

Walsh RJ, Slaby FJ, Posner BI (1987) A receptor-mediated mechanism for the transport of prolactin from blood to cerebrospinal fluid. Endocrinology 120:1846-1850.

Waters SB, Rillema JA (1988) Effect of prolactin on enzymes of lipid biosynthesis in mammary gland explants. Am J Physiol 255:E567-E571.

Zhang SQ, Kimura M, Inoue S (1995) Sleep patterns in cyclic and pseudopregnant rats. Neurosci Lett 193:125-128. 